\title{
Mobilising the dead? The place of bones and corpses in the commemoration of the Tutsi genocide in Rwanda
}

\section{Rémi Korman EHESS}

remikorman@gmail.com

\begin{abstract}
$^{1}$
Representations of Rwanda have been shaped by the display of bodies and bones at Tutsi genocide memorial sites. This phenomenon is most often only studied from the perspective of moral dimensions. This article aims in contrast to cover the issues related to the treatment of human remains in Rwanda for commemorative purposes from a historical perspective. To this end, it is based on the archives of the commissions in charge of genocide memory in Rwanda, as well as interviews with key memorial actors. This study shows the evolution of memorial practices since 1994 and the hypermateriality of bodies in their use as symbols, as well as their demobilisation for the purposes of reconciliation policies.
\end{abstract}

Key words: commemoration, human remains, memorial policy, Rwanda, symbol of memory

For the Government of National Unity, established on 19 July 1994, the memory of the Tutsi genocide was far from a priority. Confronted with considerable political challenges, it struggled for recognition and military survival at the international level. These challenges included issues over its prison population (of such great magnitude that the situation proved impossible to manage); ${ }^{2}$ the question of the millions of refugees inside and outside the country; and the return of hundreds of thousands of Tutsis who had been in exile since the beginning of the 1960 s. $^{3}$

Because of the genocide, but also because of its partly exiled population, there was a shortage of everything - administrators, parties, associations and religious officials - in post-genocide Rwanda. The Front patriotique rwandais (Rwandan Patriotic Front; FPR) continued to be the only organised institution, along with the Catholic Church. Despite all these difficulties, the Rwandan State organised commemorative ceremonies at the national level as early as 1994.

Although many commemorations were initiated after Rwandan independence in 1962, these rarely mobilised the dead, with the exception of two state funerals held in 1986 in honour of the former bishop of Nyundo, Aloys Bigirumwami, and the first president of the republic, Dominique Mbonyumutwa. ${ }^{4}$ Similarly, before 
1994 Rwanda did not have any monumental tradition and tangible heritage was mostly colonial or religious.

The display of human corpses and remains at genocide memorial sites, and during commemorations, therefore represents a twofold break which has itself been the subject of many publications. These works for the most part present an analysis of the moral dimension of these phenomena. ${ }^{5}$ In contrast, this article aims to present the place of and the issues related to the handling of human remains in Rwanda from a historical and non-normative point of view. Its goal is, in particular, to recall the role of bodies and their mourning in commemorative practices, as well as the evolution of these practices over the past twenty years. ${ }^{6}$

What meaning has therefore been given by Rwanda's new leaders to these practices of exhibiting and preserving bodies? In the definition of this new memory project, what relationships were established between the State and other actors, such as the Catholic Church or the survivors? Was the Rwandan Government ultimately inspired by traditional cultural practices, and did it develop a unique memory model or instead borrow from others? Above all, how can the evolution of the place accorded to human remains in the commemoration of the genocide between 1994 and 2014 be explained?

\section{Commemoration through bodies}

\section{The burial of victims of the genocide}

On 13 November 1994 - that is, four months after the end of the genocide - an important official ceremony took place at Muyumbu, a commune of Bicumbi in the Kigali prefecture. ${ }^{7}$ The event was not so much a commemoration of the war or of the genocide, but an official burial of the victims' bodies from this geographic area. This ceremony was carried out as part of the programme of emergency dignified burial that was managed by the Ministry of Labour and Social Affairs (Minitraso). Although in the first months after the genocide there were corpses strewn across the country, many victims remained untraceable. The search for their bodies involved both the survivors of genocide and Tutsi refugees from 1959 and 1973 who returned to the country in order to find out what had happened to their loved ones. ${ }^{8}$ However, it proved difficult to find information on the location of mass graves; perpetrator testimonies were scarce after the genocide. In the event corpses were found, and positively identified, families tried to organise traditional funeral rites, ${ }^{9}$ and the dates of funerals were broadcast on the radio. Friends were invited to a vigil and to the burial, which would most often be accompanied by a religious ceremony. Individual funerals organised after 1994, which are not well known or documented, amounted to a large number of micro- and local-level commemorations of the genocide. Remains were buried on family plots, as tradition dictated. ${ }^{10}$ This signified respect for the victims, but was also a way of reappropriating locations that had been desecrated by the killers.

As a result, a new expression appeared after the genocide: 'dignified burial' (gushyingura mu cyubahiro). The notion of dignity is linked to the concept of the victims' 'malicious death'. Both 'malicious death' (urupfu rubi) or 'dying mali- 


\section{Rémi Korman}

ciously' (gupfa nabi) implicitly refer to the cruelty applied to the bodies of the victims during the genocide. ${ }^{11}$

A new funerary ritual therefore appeared alongside this process of dignified burial. The search for bodies and their consequent exhumation (gutaburura) were its first steps. Wherever possible, the survivors then tried to collect body parts (gushyira hamwe umubiri). However, this was often impossible due to the bones being mixed together. The remains of the victims' bones were then washed and cleaned, leaving those that were still made up of flesh and naturally preserved in graves. This process was rooted in the way the body is cared for in traditional funeral rites. Accordingly, 'the act of cleaning (gukarabya) replaced ordinary rites vis-à-vis the body, such as posing (gupfunya), embalming (gusiga) or clothing the body $(k w a m b i k a)^{\prime} .{ }^{12}$

In practice, these individual and family funerals became very difficult after the genocide for logistical reasons. ${ }^{13}$ The State itself lacked funds at that time. The program of dignified burial, led by the Minitraso's employee Silas Sinyigaya, was only possible from October 1994 because of international financial assistance. The leaders of UNICEF decided to grant 150,000 dollars to the burial programme after repeatedly observing children playing soccer with skulls, ${ }^{14}$ and the World Health Organisation (WHO) contributed to the purchase of a car. Many genocide sites were visited with this vehicle, which helped to establish a 'methodology for mass burial of the genocide victims'.

The methods for collective funeral arrangements varied by location. In some places bodies were placed in coffins, whereas in others they were simply placed at the bottom of graves whose bottom was itself covered in the multipurpose tarpaulins that were widespread in Rwanda after the genocide.

Some of these ceremonies, such as those for the communes of Mugina and Ntongwe in 1994, were organised at the national level. ${ }^{15}$ When the state could not take a role, exhumation and reburial ceremonies were undertaken by the survivors themselves, aided in some places by the Catholic Church. In Butare, a group of religious and lay people brought together through the Commission de relance des activités pastorales (Commission for Relaunching Pastoral Activities) paid particular attention to these mourning ceremonies. ${ }^{16}$

Finally, the first dignified-burial program ended in early 1996, at the same time as the ceased funding from UNICEF and the WHO. It was then taken up by the Commission mémorial du génocide et des massacres (Genocide and Massacres Memorial Commission). This was the first memorial institution for the genocide; it was established in October 1995.

Following this first dignified burial program, the Minitraso was called on to organise the first official commemoration of the genocide in April 1995. ${ }^{17}$ The ceremony at the Rebero-l'Horizon site respected the spirit of national unity, based on power sharing between Tutsis and Hutus. The term 'genocide and massacres' (Itsembabwoko n'itsembatsemba) that became established during this period indicates the equal emphasis given, for political reasons, to the genocide committed against the Tutsis and to the Hutu massacres, the two being considered as inseparable. ${ }^{18}$ The first Hutu Prime Minister, Agathe Uwilingiyimana, who was murdered 
on 7 April 1994 by the presidential guard, was buried alongside an anonymous victim of the genocide committed against the Tutsis.

The burial of victims therefore constituted a key moment of the first commemoration. Large graves were dug beforehand at the Rebero site, awaiting the coffins of anonymous victims exhumed from the graves around the Centre Hospitalier de Kigali (CHK), as well as the politicians assassinated in 1994. Despite the presence of republican symbolism, the first commemoration primarily followed a religious protocol. Four masses were held during the ceremony. Catholic hymns punctuated the commemoration, and political speeches played only a relatively limited role. Indeed, this first commemoration was centred around the burial of bodies.

\section{The display practices of human remains}

The Genocide and Massacres Memorial Commission (or simply the Memorial Commission) was created in October 1995. Originally an interministerial body, it aimed to identify the main mass graves across the country in order to provide dignified burials. Where possible during its investigation, human remains that were sometimes scattered were gathered together, whether in classrooms or city offices. In some places bean storage facilities were even put to use for the 'storage' of bones for commemorative events. The report officially published by the commission in March 1996 clearly aimed to guide genocide memorial policy in Rwanda and in particular to organise future commemorations. ${ }^{19}$

This same memorial commission was responsible for the second commemoration of the genocide in 1996, which represented a break in two respects. Firstly, the preparation for the day of remembrance was characterised by a competition between the Catholic Church and the State over their legitimacy to 'mobilize the dead'. ${ }^{20}$ The commemoration of 7 April 1996 was secular, the Rwandan Government having refused to postpone its date as requested by the Church. It just so happened that the 7 April commemorative date coincided with Easter Sunday that year. This commemoration, held at the Murambi site, was consequently defined by the public displaying of the victims' bodies.

In December 1995 and January 1996, more than twenty thousand bodies were exhumed by the Amagaju local association of survivors, in conjunction with the Comité d'initiative pour l'enterrement des victimes de Murambi (Murambi Initiative Committee for the Burial of Victims; CIEM). After the site had been chosen as the venue for the second commemoration, it was decided that the burial be postponed, and lime was spread over several thousand corpses for preservation purposes. The majority of the bodies were buried on the national day of mourning, but about two thousand were kept for display and stored in the classrooms of the Murambi Ecole Technique Officielle (Official Technical School; ETO).

How can the emergence of this new practice be explained? Some researchers have seen a similarity with the displaying of bones after the Luwero War in Uganda in the 1980s, a conflict in which many Rwandan Tutsis participated before the FPR had been created. ${ }^{21}$ Others have mentioned, without establishing a direct link, the mummification practices for kings in the precolonial period. ${ }^{22}$ Studying archives relating to this subject reveals that, rather than stemming from a politi- 
cal programme, the preservation and displaying of human remains was theorised and implemented by academics from Butare in southern Rwanda. Following the reopening of the Université Nationale du Rwanda (National University of Rwanda; NUR), a group of researchers from the Tutsi diaspora met in an informal group to work on the memory of the genocide. This group was led by the archaeologist Célestin Kanimba Misago and was comprised of historians such as Joseph Jyoni wa Karega and Aloys Rufangura. It also contained some members of the Memorial Commission, such as Louis Kanamugire, Christophe Muhoza and Mario Ibarra, a Chilean who worked for the Rwandan Government for a year on the issue of bone preservation and from 1995 began producing reports for the Rwandan Government on the preservation of bodies. ${ }^{23}$ In January 1996, three months before the second commemoration of the genocide, he wrote a report on the conservation of bodies exhumed in Murambi. ${ }^{24}$

When Kanimba Misago was appointed director of the National Museum of Rwanda in 1996, he became responsible for the preservation of genocide memorial sites and bones at the national level. ${ }^{25}$ The preservation of bodies and bones became an integral part of a heritage- or even museum-based logic. Preservation entailed work on the very materials of the bodies, so that the human remains could be displayed. Pharmaceutical products were applied to slow the decomposition of flesh. The decision was made to sort and present the bones at memorials according to categories, with the most visible traces of violence being displayed.

This logic of commemorative conservation and display needs to be placed in context of the small number of significant forensic investigations in Rwanda and the persistent denial about the reality of the massacres. ${ }^{26}$ For the Rwandan authorities, bodies were the main evidence of the genocide and it was therefore important to be preserved and displayed. ${ }^{27}$ Within the body of legislative reports and texts, they are referred to as 'material evidence of genocide' (ibimenyetso bya jenoside). It should be noted that this strategy of displaying images of bones and corpses in response to the denial of the reality of the massacres was also used as evidence in the majority of the genocide trials that were being held outside Rwanda. ${ }^{28}$

In addition to their onsite presence at memorials, bodies also appeared in political speeches, witness accounts, such as during commemorations, and memorial songs. Accordingly, images of extreme violence were aired on national television during the commemorative period between 1995 and 2009. The same could be said for the very explicit nature of the song lyrics broadcast on public radio. ${ }^{29}$

Indeed, bodies quickly came to symbolise the memory of the genocide. All the major official visits to Rwanda during 1994 and 2000 were to memorial sites, where the story of the genocide was primarily told through skeletons and human remains. Among others, there were visits by the Secretaries-General of the United Nations: Boutros Boutros-Ghali to Nyarubuye on 15 July 1995 and Kofi Annan to Mwurire and Nyanza de Kicukiro on 8 May 1998. The most striking example, however, is Bill Clinton's visit to Rwanda on the eve of the fourth commemoration. When his visit was announced, the US State Department warned that the president would only stay in Rwanda for a few hours and would not leave the airport. The Rwandan Government responded by building a monument 
right on the tarmac. ${ }^{30}$ The mummified bodies and bones were transferred for the occasion from the Murambi and Nyamata sites to be displayed. In the end, Clinton did not leave the airport terminal and did not even visit the monument, which became the subject of much criticism. ${ }^{31}$ Beyond words, coming face to face with bodies and bones emerged as the political ritual for recognising the genocide.

Two years later, as the sixth commemoration of the genocide approached, tens of thousands of bodies would be exhumed in the city of Kigali. Mass graves were located mainly in the Nyamirambo sector, bodies having been buried there during the genocide as part of a 'public-health' operation. ${ }^{32}$

This massive exhumation process arose through the Kigali prefecture, led at that time by Marc Kabandana, who, inspired by a visit to the Yad Vashem memorial site in 1998, wanted to create a major genocide memorial in Kigali. The place designated for the memorial was located in Gisozi, a hill in the capital. From the sixth commemoration of 7 April 2000, the site became the largest cemetery of the genocide in Rwanda and thereafter the main museum-memorial. This commemoration was the first to take place in the presence of an important foreign dignitary - Guy Verhofstadt, the prime minister of the Kingdom of Belgium. At the occasion Verhofstadt apologised for his country's inaction and that of the international community during the genocide. Soon after this international recognition of the genocide's memory began, criticism quickly followed. In 2000 and 2001, the Rwandan Government was repeatedly accused by political opponents, as well as foreign observers and academics, of using the genocide and human remains for political purposes. Various concepts were then developed to name this political use of memory: corpse voyeurism ${ }^{33}$, instrumentalisation of genocide ${ }^{34}$ and even genocide credit. ${ }^{35}$ The Rwandan Government was therefore accused of using the dead to hide its own crimes committed during the civil war and of dismantling Hutu refugee camps in Zaire, and Western countries were accused of silence over these crimes due to their 'shame' at not having been able to stop the genocide.

To address these critical discourses on the Government's way of dealing with memory, bodies were further mobilised.

In 2001, at the seventh commemoration of the genocide, President Paul Kagame declared:

There are people who spend time ... people who like to say we are trading off the genocide ... Trading? ... They dare to say that we are treating the genocide like a business. What business can you do from genocide? What can you sell with this genocide? What is the product in the genocide that can be monetized? What is there in the genocide that we can sell? Tell me, what we can sell from the genocide? These bodies of people that we have before us? ... Whoever does not believe that genocide happened or believes that it is a business should take a moment to take in the smell in this [he fails to find the words and prefers to point to the graves] ... in these coffins $\ldots$ he should look at and feel what is in them. When people say that we are selling the genocide, I ask myself: What can we sell in this? ${ }^{36}$ 


\section{Rémi Korman}

The beginning of the twenty-first century marked an evolution in commemorative practices with the arrival of foreign actors to help with the management of the genocide's memory. Various reports were produced by foreign-aid services on the management of bodies, and memory issues were partly managed in Rwanda by the AEGIS Foundation until their management was taken over by the Rwandan Government once more in $2008 .^{37}$

\section{Towards a symbolic commemoration of the genocide?}

\section{Memorial policy and the internationalisation of memorial practices}

Provided for under the constitution passed in 2003, the Commission Nationale de Lutte contre le Génocide (National Commission for the Fight against Genocide; CNLG) was established in 2008. This body would quickly promote new memorial practices. Its stated aim was to complete the process of dignified burial.

Indeed, since 1994, bodies had not stopped being exhumed and buried or reburied. This logic of repeated burials and exhumations can be explained in several ways. Firstly, we must remember the context in which the first dignified burials in the years following the genocide occurred. Funding was inadequate at that time, which caused constant delays to the work's progress, and eventually weakened the structures in place. The materials used were of a low quality and corruption was not uncommon. Added to this was the lack of an architectural plan that took climatic effects into account. After a few years, water infiltrated the cement graves, and these eventually subsided. The poor state of the graves meant that they needed to be rebuilt, which in turn necessitated further reburials.

Other exhumations then took place because of the administrative reforms of 2001 and especially 2006, which were accompanied by the practice of decentralising memorials. Each of the thirty districts were henceforth expected to manage a main memorial. Bodies were transferred from one site to another and from smaller local memorials to sector, district or national memorials, depending on the location. Finally, the concept of dignity evolved from 1994. Graves dating from 1994 or 1995 were subsequently exhumed in order to clean the bodies and separate the human remains from clothes and objects and bury them in coffins. Rwanda's improving economic situation also explains further exhumations in the years immediately before 2010 .

In the end, however, some bodies were buried and then exhumed one, two, three or even four times because of these multiple logics. They were buried once on a family plot, a second time in a local cemetery and a third time when the local cemetery was transferred to a central cemetery, and so on. All this would take place with each commemorative period, which runs from April to July.

This painful process for families was what the National Commission for the Fight against Genocide wanted to change, focusing in particular on building sustainable structures. In recent years, the CNLG has organised the installation of, for example, impressive rain-protection structures at the main genocide memorial sites and cemeteries. Similarly, the leaders of the CNLG wished to permanently preserve the human remains on display at the memorials. Therefore, with the 
sixteenth commemoration of the genocide approaching, an international conference on the conservation of the victims' bodies of the genocide was organised in Kigali under the auspices of the National Commission for the Fight against Genocide and Cranfield University. ${ }^{38}$

As we can see, the CNLG's first priority focused on the question of the genocide's material memory: cemeteries, memorials and bodies. Rwanda's first memory law focused on this very theme. It was passed by the Rwandan Parliament in $2008 .{ }^{39}$ The law repeatedly mentions the issue of bodies. Articles 4 to 6 of the law concern the dignified burial of victims. The law states that districts should look for poorly buried bodies (imibiri yashyinguwe nabi) and also deals with unburied bodies, especially those kept for evidence or bodies that were displayed but damaged. Article 3 of the law enforces the public nature of memorials and therefore of bodies that are displayed or buried at them. This last point was the subject of much debate. If bodies were state property, what are the rights of victims' families over them? Although this law did not lead to official controversy, the CNLG proposed amendments. ${ }^{40}$ Finally, the law covered the case of victims' bodies of the genocide that had not yet been buried (imibiri y'abazize jenoside itarashyinguwe, article 12) and people who had drowned (abantu baguye mu mazi, article 13). It also punished the destruction of bodies (kwangiza imibiri y'abazize jenoside, article 21) and their theft (kwiba imibiri, article 23).

One year after the law's publication, the issue of body stealing was the subject of much debate. A report issued on the eve of the fifteenth commemoration by Deputy Evariste Kalisa, President of the parliament's human-rights committee, said that victims may have been exhumed from genocide memorials in Uganda for the purposes of witchcraft. ${ }^{41}$ Deputies then asked Joseph Habineza, the minister of culture, to intervene.

These debates show the international dimension of the genocide's memory. After being thrown into rivers during the genocide, tens of thousands of bodies ended up in Uganda and Tanzania. There were special commemorative practices for these victims and memorials were built in Uganda. At the same time, it should be noted that the 'scenographic specificity' of genocide memorials also became internationalised.

In April 2007 a memorial project to be located in a space adjoining Southwark Cathedral in London was launched. Reverend Colin Slee, Dean of Southwark, and the financier Sigmund Sternberg promised to help fund the memorial, in conjunction with the Rwandan embassy. ${ }^{42}$ Officially, the memorial was intended to be a place of memory and show, in a literal sense, the reality of the genocide. Two British artists, Ben Langlands and Nikki Bell, were selected to carry out the project. They had previously designed memorial works that had been commissioned by the Imperial War Museum. ${ }^{43}$

They visited Rwanda in February 2009 to meet with representatives of the National Commission for the Fight against Genocide and to visit the memorials. Following this visit, the minister of culture, Joseph Habineza, explained that 'experts have wished to have some art crafts made in the form of human limbs while others have thought of airlifting some remains from here to the London 


\section{Rémi Korman}

memorial but we intend to maintain the originality. ${ }^{44}$ This project was later abandoned.

\section{Euphemising commemorative practices}

The year 2010 was marked by many ruptures in the memorial process and the role afforded to human remains in the memory of the genocide. Firstly, the sixteenth national ceremony took place at the Amahoro national stadium in Kigali without any dignified burial. In other words, bodies did not take centre stage at the event. It seems that this can be explained by the special emphasis placed on the issue of trauma that year.

From 2004 there was a significant increase in trauma crises and public demonstrations of suffering in the course of national commemorations. ${ }^{45}$ The increase in the number of cases, the violence of the crisis and its spread to populations that had not experienced the genocide led the Rwandan Government to look for new commemorative forms that would limit the occurrence of such disquiet. In 2009, the Association rwandaise des conseillères en traumatisme (Rwandan Association of Trauma Counsellors; ARCT-Ruhuka), an NGO based in Kigali particularly concerned with the rape of women during the genocide, indicated that a significant portion of psychiatric disorders could be explained by the fact that survivors were traumatised by the memory of their 'still unburied relatives, not knowing where their bodies were thrown'. ${ }^{46}$

The consideration given to the issue of psychological trauma can be discerned in the sixteenth commemoration's official theme: 'Let us commemorate the Genocide against the Tutsi, uniting more closely against its trauma'. The issue of trauma and of its causes and consequences was mentioned during the commemorations and became the subject of numerous publications in the press. The situation further accelerated after the election in February 2011 of a psychologist, Jean-Pierre Dusingizemungu, as the head of the Ibuka association of survivors.

During the sixteenth commemoration it was possible to see new memorial practices. In the media and during the commemorations, violent images of bodies that had been cut with machetes gave way to documentaries that spoke of forgiveness and reconciliation. The violence was in fact euphemised. From 2010, new memorial songs, mostly commissioned by the survivors' associations or the State, were inspired and influenced by the new Pentecostal religious movements that emerged in Rwanda after the genocide. Music videos for the old songs were reshot so as to bring less violent images to the fore. ${ }^{47}$ In general, the National Commission for the Fight against Genocide encouraged artists to find new aesthetic forms to symbolise the memory of the genocide without showing the bodies of victims. The memorial project by the artist Bruce Clarke provides the most striking example. Genocide victims were represented as 'upright men' (hommes debout) - as silhouettes of their past lives and not as dead bodies. ${ }^{48}$ Finally, CNLG adopted an official symbol of the genocide which would henceforth appear on all communication: the flame of hope (urumuri rw'icyizere).

A new political discourse was then brought to the memorial process. It was based around the concepts of healing, ${ }^{49}$ reconciliation and, indirectly, resurrection. 
Evidence of the genocide and the remains of the victims became proof of the rebirth of the new Rwanda (Rwanda rushya). The bodies of the victims were likened to the body of Rwanda, thus, during the seventeenth commemoration of the genocide in 2011, President Paul Kagame declared: 'The body of Rwanda was tortured, assaulted, and succumbed but the spirit never died. It is that spirit that should fight on, that spirit will never and should never be defeated. Defending Rwanda's spirit is within our reach and means. ${ }^{50}$

This psychological transformation of the Rwandan nation - described as resilient - is reflected in the official song of the nineteenth commemoration, entitled 'Umujinya mwiza' ('Good Anger'). For the fiftieth anniversary of independence in July 2012, the song A Journey to Resilience (Chemin vers la résilience) was celebrated as having been made since the genocide. This rebirth of the body of Rwanda was also extended to the imagining of a vital resurrection in Rwandan society - even more relevant as the genocide commemorations were taking place in April and during the Easter period. This synthesis of rebirth and resurrection can be found in part of the seventeenth commemoration's official song's chorus: 'The genocide is Rwanda's cross'. ${ }^{51}$

Finally, political control over the issue of bodies can also be observed through the attempt to control memorial language. In its annual reports published since 2004, the Haut Conseil des Médias (Media High Council) has listed journalists' errors and abuses of language. In 2011, it published a new report calling for the use of 'more appropriate' words to speak of genocide. ${ }^{52}$ There was a desire to mention that the genocide was committed against the Tutsis and to fight against the 'traumatic words' used by some in Rwanda or the diaspora to speak of human remains. ${ }^{53}$ Expressions such as ibisigazwa (remains, in a general sense) or intumbi (the human or animal body) were prohibited. Similarly, the committee urged people to stop using the word amagufa (human or animal bones), which was used by the majority of Rwandans and survivors. It proposed the use of the term imibiri y'abazize Jenoside yakorewe Abatutsi (the bodies of the people killed during the genocide committed against the Tutsis).

This desire for memorial language to evolve has an ethical dimension, aiming to restore dignity to those who disappeared. In the case of natural deaths in Rwanda, people continue to use the term corpse (umurambo) and not body, used in referring to the genocide's victims (umubiri). In the same way and in relation to the exhumations, the verb gutaburura (dig up) was replaced by gushakisha (search for). But this evolution of memorial language is also an indicator of a political will to pacify the genocide's memory.

This progressive euphemisation of the memory of the genocide was ultimately seen at the twentieth commemoration of the genocide in 2014. Firstly, the genocide commemorations were preceded by a 'precommemorative' period of almost three months. From January to April 2014, a flame of hope circulated in each of Rwanda's thirty districts. It was accompanied by political speeches, witness accounts and songs, but never burials. The day of mourning organised at the Amahoro national stadium in Kigali on 7 April 2014 was likewise supposed to be symbolic. The stadium is not a massacre site and no burial was organised for the 


\section{Rémi Korman}

event. Although dignified burials took place at local commemorations in 2014, particularly in Bisesero and Rubavu, new commemorative forms also emerged.

Survivors' associations organised commemorations that were no longer centred on memorial sites or the materiality of the bodies. They suggested ceremonies in memory of people thrown into Rwandan rivers, raped and murdered women and families that had entirely disappeared (Imiryango yazimye muri jenoside yakorewe abatutsi). Commemorations were finally organised for people whose bodies have not been found. ${ }^{54}$

\section{Conclusion: towards a commemoration without corpses or remains?}

Studying the commemorative practices over the past twenty years sheds light on the evolution of the role given to human remains. Their public exhibition from 1996 is part of a multifaceted set of wishes. First of all there was the desire to keep alive the memory of the genocide; in a context of a civil war that continued until the start of the twenty-first century, and in the context of the Congo wars, the bodies echoed the risk of destruction. The exhibition of human remains was part of an effort to fight against genocide denial. ${ }^{55}$ In the absence of financial means, human remains were the genocide's most concrete physical evidence.

How can the euphemisation of memorial practices since the end of the first decade of the twenty-first century be explained? It is the product of political evolution, the source of which was the re-election of Paul Kagame as President of the Republic in 2010 for a second term. From this moment on, there was a willingness to make the genocide a thing of the past. The judicial process has been changing, with the closure of the Gacaca system in 2012, and the memorial process has followed a parallel path; the CNLG wishes to bring a close to the dignified burial process and find a permanent storage solution for the displayed human remains.

Genocide is no longer presented as part of the present; it has become a founding element of the Rwandan nation. Fragmented bodies of victims are no longer mobilised in the commemorations and have given way to speeches on the unified body of the new Rwanda. More so than the memory of the genocide, reconciliation is now at the heart of the memorial process. The demobilisation of the dead indicates the political will to 'emerge from the genocide ${ }^{56}$ but the decision to close the memorial and legal processes has come up against the demands of many survivors who fear a trivialisation of the genocide's memory.

\section{Notes}

1 Translated from the author's French by Cadenza Academic Translations.

2 M. Wagner, 'The War of the Cachots: A History of Conflict and Containment in Rwanda', in F. Bernault (ed.), A History of Prison and Confinement in Africa (Portsmouth, Heinemann, 2003), pp. 239-70; C. Tertsakian, Le Château: The Lives of Prisoners in Rwanda (London, Arves, 2008).

3 See A. Guichaoua (ed.), Exilés, Réfugiés, Déplacés en Afrique Centrale et Orientale (Paris, Karthala, 2004). 
4 Little has been written so far on commemorations held during the first two republics. See, however, R. Nkaka, 'Commémorations Nationales et Ethnicisation/ Racialisation de la Société Rwandaise’, Dialogue, 199 (2012), 99-122.

5 On this point see the research of Claudine Vidal, which makes use of Paul Ricoeur's work on 'just memory', and also the works of Sarah Guyer, Jens Meierhenrich and Anna-Maria Brandstetter. See C. Vidal, 'La Commémoration du Génocide au Rwanda', Cahiers d'Études Africaines, 175 (2004), 575-92; S. Guyer, 'Rwanda's Bones', Boundary, 36 (2009), 155-75; J. Meierhenrich, 'Topographies of Remembering and Forgetting: The Transformation of Lieux de Mémoire in Rwanda', in S. Straus \& L. Waldorf (eds), Remaking Rwanda: State Building and Human Rights after Mass Violence (Madison, University of Wisconsin, 2011), pp. 283-315; A.-M. Brandstetter, Contested Pasts: The Politics of Remembrance in PostGenocide Rwanda (Wassenaar, Netherlands Institute for Advanced Study in the Humanities and Social Sciences, 2010), pp. 6-22.

6 There are similarities in this sense with the approach developed by Rachel Ibreck. See R. Ibreck, 'A Time of Mourning: The Politics of Commemorating the Tutsi Genocide in Rwanda', in P. Lee \& P. N. Thomas (eds), Public Memory, Public Media and the Politics of Justice (London, Palgrave Macmillan, 2012), pp. 98-120; R. Ibreck, 'The Politics of Mourning: Survivor Contributions to Memorials in Post-Genocide Rwanda', Memory Studies, 4 (2010), 330-43.

7 This passage is a revised translation of a published article on this question. See R. Korman, 'Le Rwanda Face à ses Morts ou les Cimetières du Génocide comme Lieux de Mémoire’, Génocides et Politiques Mémorielles (2012). URL: http://chs. univ-paris1.fr/genocides_et_politiques_memorielles/?Le-Rwanda-face-a-sesmorts-ou-les (accessed 15 March 2015).

8 On the application of this approach to Bosnia, see É. Claverie, 'Réapparaître: Retrouver les Corps des Personnes Disparues Pendant la Guerre en Bosnie', Raisons Politiques, 41:1 (2011), 13-31.

9 In Rwanda there has been no DNA identification of bodies. Identification was made possible through carried identity cards or even clothing worn by the victims.

10 It should be noted that literature on funeral rites in Rwanda is fairly sparse. Above all, along with other work on Rwandan culture, it is presented in an ahistorical and ageographical way. It also focuses on deaths through natural causes. See, however, G. Spijker, Les Usages Funéraires et la Mission de l'Église: Une Etude Anthropologique et Théologique des Rites Funéraires au Rwanda (Kampen, Kok, 1990).

11 See F. Baillette, 'Figures du Corps, Ethnicité et Génocide au Rwanda', Quasimodo, 6 (2000), 7-38; K. Krüger, 'The Destruction of Faces in Rwanda 1994: Mutilation as a Mirror of Racial Ideologies', L'Europe en Formation, 357:3 (2010), 91-105; R. Korman, 'The Tutsi Body in the 1994 Genocide: Ideology, Physical Destruction and Memory', in É. Anstett \& J.-M. Dreyfus, Destruction and Human Remains (Manchester, Manchester University Press, 2014), pp. 226-42. The question of malicious death also relates to evil spirits. On this point see M.-O. Godard, Rêves et Traumatismes ou la Longue Nuit des Rescapés (Toulouse, Erès, 2003).

12 See D. Gishoma \& C. Kanazayire, 'Les Commémorations du Génocide au Rwanda: 


\section{Rémi Korman}

Un Espace Transitionnel pour Métaboliser le Passé Qui ne Passe Pas?', in J.-L. Brackelaire, M. Cornejo \& J. Kinable, Violence Politique et Traumatisme (Louvain La Neuve, Editions Academia, 2013), pp. 317-37.

13 From the mid-1990s, individual exhumations were subject to authorisation and then prohibited, thereafter needing to be organised by the administration. In the early 2000s, the choice was made by the Rwandan State to organise exhumation and dignified reburials in the month of April only.

14 'Unicef Plans to Help Rwanda to Bury Dead', The New York Times, 10 December 1994.

15 Regarding dignified burial in Mugina, see F. Rutembesa \& E. Mutwarasibo, Amateka ya Jenoside yakorewe Abatutsi muri Mugina (Kigali, CNLG, 2009), 110-20.

16 Vidal, 'La Commémoration du Génocide', 577-8.

17 These reflections are from R. Korman, 'L'État Rwandais et la Mémoire du Génocide', Vingtième Siècle. Revue d'Histoire, 122:2 (2014), 87-98.

18 On the evolution of terms for the genocide, see Assumpta Mugiraneza, 'Les Écueils dans l'Appréhension de l'Histoire du Génocide des Tutsis', Revue d'Histoire de la Shoah, 190 (2009), 153-72, 160-2.

19 MINESUPRES, Rapport préliminaire d'identification des sites du génocide et des massacres (Kigali, 1996).

20 In discussing the period after World War One, Jay Winter mentions the Catholic Church's desire to demobilise the dead. See J. Winter, Sites of Memory, Sites of Mourning: The Great War in European Cultural History (Cambridge, Cambridge University Press, 1995), p. 26.

21 M. Mamdani, When Victims Become Killers: Colonialism, Nativism, and the Genocide in Rwanda (Princeton, Princeton University Press, 2002), p. 3.

22 See Vidal, 'La Commémoration du Génocide'.

23 R. Korman, 'Burial or display?: The Politics of Exhumation in post Genocide Rwanda', in É. Anstett \& J.-M Dreyfus (eds), Human Remains and Identification: Mass Violence, Genocide and the 'Forensic Turn' (Manchester, Manchester University Press, 2015), pp. 203-20.

24 Archives of the Genocide and Massacres Memorial Commission, Kigali. Preliminary report on the possibilities for conserving the Murambi (Gikongoro) site, by M. Ibarra, 7 January 1996.

25 Personal archives of Célestin Kanimba Misago, Butare: report entitled 'Actions de Sauvetage des Ossements et Objets pour les Musées du Génocide et des Massacres', by Célestin Kanimba Misago, 1996.

26 Two forensic inquiries were conducted in 1996 as part of the work of the International Criminal Tribunal for Rwanda (ICTR), at Home Saint-Jean in Kibuye and at the Amgar garage in Kigali. Because of the poor relations between the Rwandan State and the Arusha tribunal, no further investigation of this type has been held since.

27 In fact the absence of records must be qualified, in view of the Rwandan sources used at the ICTR. However, these remain largely unknown in Rwanda, especially after the genocide. They are also more abstract. 
28 On this point, see Marie-France Collard's film Bruxelles-Kigali. In it, speeches by a witness claiming never to have seen corpses in Kigali during the genocide is juxtaposed with a video found in the Orinfor archives. Filmed in April 1994 by Rwandan journalists, it shows the pervasiveness of bodies in the streets of Kigali. M.-F. Collard, Bruxelles-Kigali, Brussels, Cobra Films, 2011.

29 D. Gishoma, 'Crises Traumatiques Collectives d'Ihahamuka lors des Commémorations du Génocide des Tutsi: Aspects Cliniques et Perspectives Thérapeutiques', PhD dissertation, Université catholique de Louvain, 2014, 71.

30 A work by Jean-Baptiste Sebukangaga was installed on the monument.

31 J. Chatain, 'Clinton inspecte les Grands Lacs', L'Humanité, 25 March 1998.

32 N. Eltringham, 'Exhibition, Dissimulation et "Culture”: Le Traitement des Corps dans le Génocide Rwandais', in É. Anstett \& J.-M Dreyfus (eds), Cadavres Impensables, Cadavres Impensés: Approches Méthodologiques du Traitement des Corps dans les Violences de Masse et les Génocides (Paris, Éditions Petra, 2012), pp. 93-105, 100-2.

33 Vidal, 'La Commémoration du Génocide', 582-6.

34 R. Brauman, S. Smith \& C. Vidal, 'Politique de Terreur et Privilège d'Impunité au Rwanda', Esprit, 8 (2000), 147-61.

35 This term very soon appeared in the writing of the Belgian academic Filip Reyntjens. See F. Reyntjens, 'Rwanda: Genocide and Beyond', Journal of Refugee Studies, 9:3 (1996), 240-51.

36 Gishoma, 'Crises Traumatiques Collectives', 69.

37 See, for example, S. E. Cook, 'The Politics of Preservation in Rwanda', in S. E. Cook (ed.), Genocide in Cambodia and Rwanda: New Perspectives (New Haven, Transaction Publishers, 2004), 293-311; R. Ibreck, 'International Constructions of National Memories: The Aims and Effects of Foreign Donors' Support for Genocide Remembrance in Rwanda', Journal of Intervention and Statebuilding, 7:2 (2013), 149-69.

38 G. Muramira, 'Genocide Experts Meet in Kigali', The New Times, 2 June 2010.

39 Official gazette of the Republic of Rwanda, 'Law Governing Memorial Sites and Cemeteries of Victims of the Genocide against the Tutsi in Rwanda', No. 56, 2008, 62-77.

40 G. Kanzayire, 'Ibitekerezo ku ihindurwa ry'itegeko no. 56/2008 ryo kuwa 10/09/2008 rigena inzibutso n'amarimbi by'abazize jenoside yakorewe Abatutsi mu Rwanda' ['Propositions with a view to changing law no. 56/2008 of 10 September 2008 on genocide memorials and cemeteries for the victims of the genocide committed against the Tutsis in Rwanda], Icyizere Newspaper, 15, Kigali, CNLG, 2011, 9, 13.

41 E. Rugirigiza, 'Une Sépulture Digne pour les Corps Échoués en Ouganda en 1994', Agence Hirondelle, 24 March 2009 ; See also T. Munyaneza, 'Coup d'CEil sur le Rapport des Victimes du Génocide commis contre les Tutsi Jetées dans des Rivières Rwandaises vers le Lac Victoria', Dialogue, 190 (2010), 27-34.

42 I. Mugabo, 'Genocide Memorial Site to be Erected in London', The New Times, Kigali, 12 April 2007. 


\section{Rémi Korman}

43 See in particular their work 'The House of Osama Bin Laden'. URL: http://www. langlandsandbell.com/ (accessed 18 March 2015).

44 E. Musoni, 'Genocide Memorial Site to be Constructed in London', The New Times, Kaigali, 29 April 2009. Translated quote taken from UK Africa Post. URL: http://uk-africa.blogspot.ca/2009/04/genocide-memorial-site-to-be.html (accessed 18 March 2015).

45 S. Audoin-Rouzeau \& H. Dumas, 'Le Génocide des Tutsi Rwandais Vingt Ans Après', Vingtième Siècle: Revue d'Histoire, 122:2 (2014), 3-16, 12-16; As explained by Rachel Ibreck, '[w]hile some participants are provoked to tears and distress as survivors recount their testimony, others appear to be transported back to the moment of the genocide and begin crying or trying to flee'. See R. Ibreck, 'A Time of Mourning', 109.

46 E. Rugirigiza, 'Augmentation des troubles psychiatriques liés au génocide', Agence Hirondelle, 18 February 2009.

47 The CNLG website banner was also redone, the latter previously made of bones.

48 See http://www.uprightmen.org/ (accessed 25 March 2015).

49 Research could be conducted on the mobilisation of the ubiquitous concept of 'healing' in Rwanda, covering medical and religious vocabulary.

50 Speech available on the following website: http://www.paulkagame.com/index. $\mathrm{php} / \mathrm{speeches} / 314$-president-kagame-speech-at-the-17th-commemoration-of-thegenocide-against-the-tutsis-kigali-7th-april-2011 (accessed 25 March 2015).

51 This line, Jenoside yakorewe abatutsi niwo musaraba w'uru Rwanda, appears in the Kizito Mihigo song entitled 'Twanze gutoberwa Amateka' ('We Reject the Falsification of History').

52 J.-P. Uwimana, P. Mfurankunda \& P. Peacemaker Mbungiramihigo, Appropriate Journalistic Language in Relation to Genocide against Tutsis in Rwanda: Key Guidelines (Kigali, Media High Council, 2011).

53 É. Ntakirutimana, 'Les Paroles Traumatisantes: Un Défi Langagier à Relever', in 16 Ans après le Génocide Perpétré contre Les Tutsi (1994-2010): Gestion de Ses Conséquences (Kigali, CNLG, 2011).

54 Gishoma, 'Crises Traumatiques Collectives', 81.

55 This effort was also accompanied by various laws in the first decade of the twentyfirst century (the 2003 law against the crime of genocide and the 2008 law on genocide ideology). See S. Kazuyuki, 'Beyond Dichotomies: The Quest for Justice and Reconciliation and the Politics of National Identity Building in Post-Genocide Rwanda', PhD dissertation, University of Bradford, 2009.

56 While there has been a lot of reflection on emerging from war, the issue of emerging from the genocide is still a field of study to explore. 